\title{
Value Addition in Guava through Different Pre harvest Nutrient Sprays to Improve Sensory Attributes and Storability
}

\author{
Priya Awasthi $^{1 *}$, Subhash Chandra Singh ${ }^{1}$ and Shant Lal ${ }^{2}$ \\ ${ }^{1}$ College of Horticulture, BUAT, Banda (U.P.), India \\ ${ }^{2}$ Department of Horticulture GBPUA \& T Pantnagar \\ *Corresponding author
}

\section{A B S T R A C T}

Keywords

Shelf life,

Organoleptic,

Storage,

Acceptability,

Guava, Texture,

Article Info

Accepted:

12 January 2021

Available Online:

10 February 2021
The present investigation was carried out at Horticulture Research Centre, Patharchatta and Department of Horticulture, G.B. Pant University of Agriculture and Technology, Pantnagar (Uttarakhand) during to find out the optimum nutrient concentration for sensory attributes and storability of guava cv. Sardar during winter season. The experiment was done on six year old healthy, uniform trees of guava planted at $8 \times 8 \mathrm{~m}$ distance. Two foliar sprays of four nutrient in two concentration were done in the month of September and October, respectively. Calcium nitrate 1 per cent scored overall highest marks over other treatments during storage and proved superior in organoleptic evaluation. Shelf-life was found maximum with 1 per cent calcium nitrate and minimum shelf-life was recorded with control.

\section{Introduction}

Guava is an important perishable fruit having short storage life so there is a need to search out possibilities for long term storage of the fruits. Guava fruit is mostly consumed fresh and also processed into a variety of products such as jam, jelly, cheese, toffee, juice, squash, wine and dried fruit. Pre-harvest foliar sprays of nutrients during the period of fruit growth and development have shown remarkable improvement in the quality and shelf-life of several sub-tropical and tropical fruit crops. In countries like India, where sufficient refrigeration facilities and continuous power supply are the limiting factor, the use of pre-harvest cultural practices are worth considering. Guava fruits have to be marketed immediately after harvest. Most of the cultivars can be stored only for a short period at room temperature. Considering its short shelf-life, work have been carried out to enhance it for the longer availability of fresh fruits (Hiwale and Singh, 2003).

\section{Materials and Methods}

The present investigation was conducted at the Horticulture Research Centre, Patharchatta and Department of Horticulture, 
G.B. Pant University of Agriculture and Technology, Pantnagar district U.S. Nagar (Uttarakhand) from July, 2004 to January 2006. The experimental material consisted of six years old healthy, uniform trees of guava cv. Sardar planted at $8 \times 8 \mathrm{~m}$ distance and maintained under uniform cultural practices. One leaf pair pruning was done in all the trees in the first week of May for getting winter crop. The Experiment was laid out in Randomized Block Design (RBD). All the treatments including control was replicated thrice and one tree served as a unit of replication. The total number of trees marked for experiment were twenty one. Spraying was done at around 10.00 a.m. using high volume foot sprayer. Two sprays at one month interval starting from September 3, 2004 and another was on October 3, 2004. Each experimental tree was sprayed with 8 litre solution. In all, there were three trees in each treatment hence 24 litre solution of each concentration was prepared. Various treatments include double foliar sprays of Calcium nitrate $(1.0 \%)$, Calcium nitrate $(1.5 \%)$, Boric acid $(0.2 \%)$, Boric acid $(0.3 \%)$, Zinc sulphate $(1.5 \%)$, Zinc sulphate $(2.0 \%)$ and Control (water spray). For assessing other quality attributes such as acceptability, colour and texture of guava fruits, organoleptic evaluation was done by a panel of judges. The score card of such an organoleptic evaluation carried a total of 12 marks with 4 marks for each of the above attributes.

The average marks were calculated for final assessment. For every evaluation the composite fruit samples were drawn from each and every replication of each treatment. The second part of the experiment was designed so as to observe the effect of treatment in relation to storage quality of guava fruits. For this purpose, on the day of harvesting a set of 20 fruits of uniform size and maturity were selected replication-wise from each tree and stored at room temperature. Day to day storage conditions were examined. During the period of storage quality and organoleptic evaluation was also done during storage at three days interval upto 9 days.

\section{Results and Discussion}

Fruit acceptability was found to be highest with $\mathrm{T}_{1}$ followed by $\mathrm{T}_{2}$ and lowest acceptability was found under control $\left(\mathrm{T}_{7}\right)$ in first year. In the second year similar pattern was obtained (Table 1 and 2). In case of storage period, highest acceptability was obtained at the day of harvest (zero day) and lowest at $9^{\text {th }}$ day of harvest in first year and in second year similar trend was followed. Acceptability of the fruits was found maximum with 1 per cent calcium nitrate at $9^{\text {th }}$ day of storage because the fruits treated with calcium salt had better firmness during storage as it reduced the activity of softening enzymes, i.e. polygalactouronase and pectinmethylesterase by protecting stiff pectin macromolecules against demethylation or educed depolymerisation of polygalactouronase polymers (Singh and Narayana, 1999). Firmness of the fruits in terms of pressure was found to reduce with the increase in storage period. In control fruits due to excessive moisture loss from the surface of the fruits which makes the skin hard and dry (Adsule and Kadam, 1995). Calcium application was also reported to have reduced the storage breakdown and disease incidence and controlled the rotting.

The data on the change in colour development of fruits presented in Table 1 and 2 indicate that minimum colour development was observed with $T_{1}$ followed by $T_{2}$ and maximum with $\mathrm{T}_{7}$ in fist year. In the second year, also colour development was found minimum with $\mathrm{T}_{1}$ and maximum with $\mathrm{T}_{7}$ (control). 
Table.1 Effect of different nutrients and storage period on organoleptic evaluation of the fruit during winter season in first year

\begin{tabular}{|c|c|c|c|c|c|c|c|c|c|c|c|c|c|c|c|}
\hline \multirow[t]{2}{*}{ Treatments } & \multicolumn{5}{|c|}{ Acceptability (after days) } & \multicolumn{5}{|c|}{ Colour development (after days) } & \multicolumn{5}{|c|}{ Texture (after days) } \\
\hline & $\mathbf{0}$ & 3 & 6 & 9 & Mean & $\mathbf{0}$ & 3 & 6 & 9 & Mean & $\mathbf{0}$ & 3 & 6 & 9 & Mean \\
\hline $\mathbf{T}_{1}$ & 4.00 & 3.51 & 3.00 & 2.64 & 3.29 & 0.00 & 0.61 & 2.39 & 3.13 & 1.53 & 4.00 & 3.18 & 3.00 & 2.75 & 3.23 \\
\hline $\mathbf{T}_{2}$ & 4.00 & 3.40 & 2.62 & 2.04 & 3.01 & 0.00 & 0.86 & 2.96 & 3.50 & 1.83 & 4.00 & 3.06 & 2.82 & 2.64 & 3.13 \\
\hline $\mathbf{T}_{3}$ & 4.00 & 3.00 & 2.31 & 1.64 & 2.74 & 0.00 & 1.04 & 3.14 & 3.68 & 1.96 & 4.00 & 2.44 & 2.12 & 1.85 & 2.60 \\
\hline $\mathbf{T}_{4}$ & 4.00 & 2.82 & 2.21 & 1.22 & 2.56 & 0.00 & 1.13 & 3.19 & 3.66 & 1.99 & 4.00 & 2.21 & 1.91 & 1.50 & 2.40 \\
\hline $\mathbf{T}_{5}$ & 4.00 & 2.31 & 1.63 & 1.17 & 2.28 & 0.00 & 1.23 & 3.53 & 3.92 & 2.17 & 4.00 & 2.01 & 1.82 & 1.21 & 2.26 \\
\hline $\mathbf{T}_{6}$ & 4.00 & 2.60 & 2.21 & 1.41 & 2.55 & 0.00 & 1.32 & 3.42 & 3.95 & 2.18 & 4.00 & 2.06 & 1.94 & 1.22 & 2.30 \\
\hline $\mathbf{T}_{7}$ & 4.00 & 2.31 & 1.44 & 1.03 & 2.19 & 0.00 & 2.42 & 3.79 & 3.96 & 2.54 & 4.00 & 1.85 & 1.42 & 0.91 & 2.04 \\
\hline \multirow[t]{2}{*}{ Mean } & 4.00 & 2.85 & 2.20 & 1.59 & 2.66 & 0.00 & 1.23 & 3.20 & 3.69 & 2.03 & 4.00 & 2.40 & 2.15 & 1.72 & 2.57 \\
\hline & \multicolumn{3}{|c|}{ S.Em. \pm} & \multicolumn{2}{|c|}{ C.D. at $5 \%$} & \multicolumn{3}{|c|}{ S.Em. \pm} & \multicolumn{2}{|c|}{ C.D. at $5 \%$} & \multicolumn{3}{|c|}{ S.Em. \pm} & \multicolumn{2}{|c|}{ C.D. at $5 \%$} \\
\hline Storage period & \multicolumn{3}{|c|}{0.841} & \multicolumn{2}{|c|}{0.238} & \multicolumn{3}{|c|}{0.923} & \multicolumn{2}{|c|}{0.265} & \multicolumn{2}{|c|}{0.799} & & \multicolumn{2}{|c|}{0.226} \\
\hline Treatments & \multicolumn{3}{|c|}{0.111} & \multicolumn{2}{|c|}{0.315} & \multicolumn{3}{|c|}{0.123} & \multicolumn{2}{|c|}{0.350} & \multicolumn{2}{|c|}{0.105} & & \multicolumn{2}{|c|}{0.299} \\
\hline Interaction & \multicolumn{2}{|c|}{0.222} & & \multicolumn{2}{|c|}{0.631} & \multicolumn{2}{|c|}{0.267} & & \multicolumn{2}{|c|}{0.701} & \multicolumn{2}{|c|}{0.211} & & \multicolumn{2}{|c|}{0.599} \\
\hline $\begin{array}{ll}0.00 & : \\
4.00 & :\end{array}$ & $\begin{array}{l}\text { Non acce } \\
\text { Excellent }\end{array}$ & ble, & & $\begin{array}{l}: \\
:\end{array}$ & $\begin{array}{l}\text { Gre } \\
\text { Yel }\end{array}$ & & $\begin{array}{l}0.00 \\
4.00\end{array}$ & $:$ & $\begin{array}{l}\text { Rough } \\
\text { Smooth }\end{array}$ & $\begin{array}{l}\text { xture } \\
\text { xture }\end{array}$ & & & & & \\
\hline
\end{tabular}

Table.2 Effect of different nutrients and storage period on organoleptic evaluation of the fruit during winter season in second year

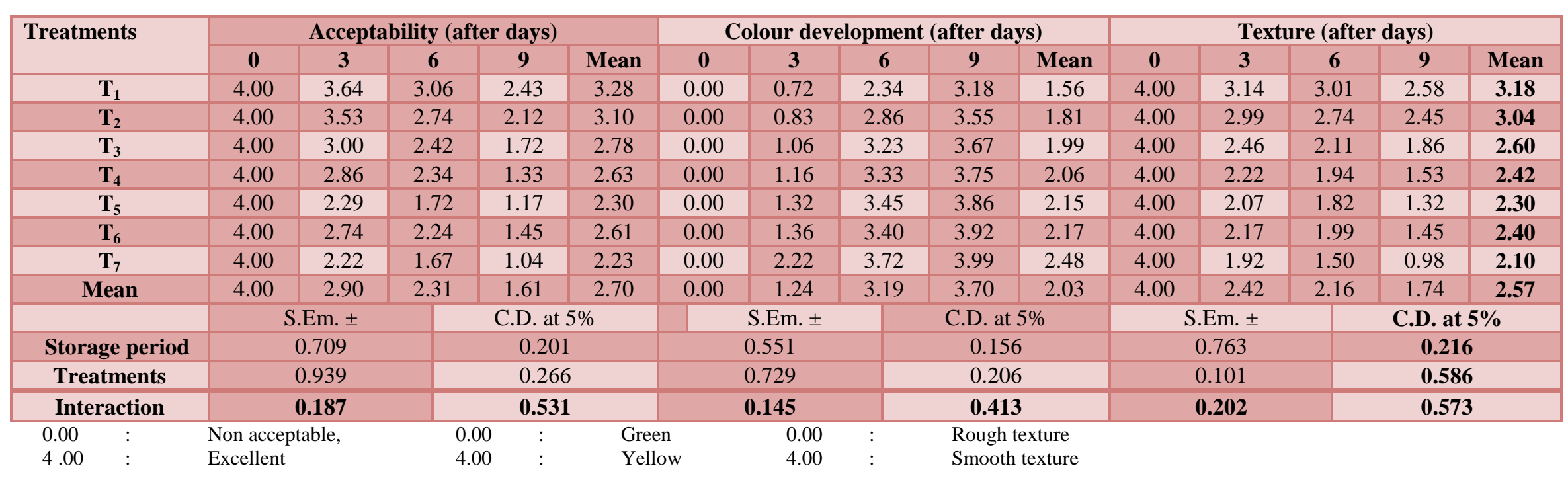


Table.3 Effect of different nutrients on total marks of the fruit in organoleptic evaluation during winter season

\begin{tabular}{|c|c|c|}
\hline \multirow{2}{*}{ Treatments } & \multicolumn{2}{|c|}{ Total marks } \\
\cline { 2 - 3 } & $\mathbf{I}^{\text {st }}$ year & II $^{\text {nd }}$ year \\
\hline $\mathbf{T}_{\mathbf{1}}$ & 8.04 & $\mathbf{8 . 0 2}$ \\
\hline $\mathbf{T}_{\mathbf{2}}$ & 7.97 & $\mathbf{7 . 9 5}$ \\
\hline $\mathbf{T}_{\mathbf{3}}$ & 7.30 & $\mathbf{7 . 3 7}$ \\
\hline $\mathbf{T}_{\mathbf{4}}$ & 6.95 & $\mathbf{7 . 1 1}$ \\
\hline $\mathbf{T}_{\mathbf{5}}$ & 6.71 & $\mathbf{6 . 7 5}$ \\
\hline $\mathbf{T}_{\mathbf{6}}$ & 7.03 & $\mathbf{7 . 1 8}$ \\
\hline $\mathbf{T}_{\mathbf{7}}$ & $\mathbf{6 . 7 7}$ & $\mathbf{6 . 8 1}$ \\
\hline
\end{tabular}

Table.4 Effect of different nutrients on shelf-life of the fruit during winter season

\begin{tabular}{|c|c|c|}
\hline \multirow{2}{*}{ Treatments } & \multicolumn{2}{|c|}{ Shelf-life (days) } \\
\hline & $I^{\text {st }}$ year & II $^{\text {nd }}$ year \\
\hline $\mathbf{T}_{1}$ & 8.23 & 8.50 \\
\hline $\mathbf{T}_{2}$ & 7.66 & 8.16 \\
\hline $\mathbf{T}_{3}$ & 6.25 & 6.66 \\
\hline$T_{4}$ & 5.75 & 6.00 \\
\hline & 5.25 & 5.16 \\
\hline $\mathbf{T}_{6}$ & 5.08 & 5.16 \\
\hline $\mathbf{T}_{7}$ & 2.25 & 1.91 \\
\hline S.Em. \pm & 0.156 & 0.322 \\
\hline C.D. at 5\% & 0.481 & 0.992 \\
\hline
\end{tabular}

In respect of storage period, the colour development towards yellow from green, minimum colour development was recorded at the day of harvest (zero day) and maximum colour development was recorded at $9^{\text {th }}$ day of storage in first year. Same pattern was found in second year. It may be due to retardation of chlorophyll decomposition and subsequent inhibition of ripening process (Singh et al., 1993). Calcium salts might have increased the activity of chlorophyllase enzyme which is responsible for breakdown of chlorophyll and enhanced $\beta$-carotene content in the fruits (Singh et al., 1998). Involvement of various enzymes in chlorophyll degradation in the stay green fruits of "Cavendish' banana and 'Langra' mango (Janave, 1997; Janave and Sharma, 2004 a,b). Data presented in Table 1 and 2 showed that minimum texture change was obtained in $T_{1}$, while maximum texture change was obtained in $\mathrm{T}_{7}$ (control) in first year. Similar pattern was also recorded in second year. With respect to storage period, minimum texture change was obtained at $9^{\text {th }}$ day of storage and maximum was found at the day of harvest in all the treatments followed by at $3^{\text {rd }}$ day of storage in first year. During second year, similar trend was found. Calcium compounds helped in sustain texture as proportion molecules in the middle lamella were reinforced with exogenous calcium thereby retarding hydrolysis (Jagadeesh et al., 2001).

The fruit firmness was also increased with calcium treatments, which forms a part of cell 
wall as calcium pectate and calcium reduced the rate of respiration, which might also reflect inhibition of ethylene evolution and activation of pectolytic enzymes, thus maintained the texture of the fruits (Bakshi et al., 2005). Maximum texture change in control fruits may be due to more physiological loss in weight and volume by way of more respiration could be correlated to their more shrivelling, roughness and loss of glossiness (Adsule, 1973).

Different nutrients significantly influenced the organoleptic evaluation of the fruits in both the years. The organoleptic evaluation was found highest in 1 per cent calcium nitrate followed by 1.5 per cent calcium nitrate at the day of harvest and also at $9^{\text {th }}$ day after harvest, in comparison to other treatments including control. In all the treatments including control, in general, organoleptic rating was decreased with the increase in storage period (Table 3 ).

Different nutrients had significant effect on the shelf-life of the fruits in both the years (Table 4). Calcium nitrate 1 per cent resulted maximum shelf-life of the fruits over all other treatments including control. Calcium compounds extended the shelf-life of many fruits by maintaining firmness, and minimizing the rate of respiration, protein breakdown and disease incidence (Bangerth $e t$ al., 1972; Sharples and Johnson, 1976 and Gupta et al., 1979). The calcium treatment reduced the activity of various oxidative and reductive enzymes as well as ethylene production resulting in extension of shelf-life in guava (Hiwale and Singh, 2003). Thus, calcium as an essential nutrient involved in a number of physiological processes of fruit, involving in maintaining cell wall integrity and found to inhibit, to some extent, senescence and prolonged shelf-life of the fruits (Roychoudhury et al., 1992).

\section{References}

Adsule, R.N. and Kadam, S.S. 1995. Guava. Hand Book of Fruit Science and Technology. pp. 419-433.

Adsule, V.M. 1973. Changes during storage of mango. Indian Fd. Pack. 24(1) : 2528.

Bakshi, P.; Masoodi, F.; Chauhan, G.S. and Shah, Ta. 2005. Role of calcium in postharvest life of temperate fruits : A review. J. Food Sci. Technol. 42(1) : 18.

Bengerth, F.; Dilley, D.R. and Dewey, D.N. 1972. Effect of post-harvest calcium treatments on internal breakdown and respiration of apple fruits. J. Amer. Soc. Hort. Sci. 97 : 679-682.

Gupta, O.P.; Singh, B.P. and Gupta, A.K. 1979. Studies on the shelf-life of different guava cultivars. Haryana Agric. Univ. J. Res. 1(3) : 247-350.

Hiwale, S.S. and Singh, S.P. 2003. Prolonging the shelf-life of guava (Psidium guajava L.). Indian J. Hort. 60(1) : 1-9.

Jagadeesh, S.L.; Rokhade, A.K. and Lingaraju, S. 2001. Influence of postharvest treatments on storage behaviour of guava fruits cv. Sardar. $J$. Maharastra Agric. Univ. 26(3) : 297300.

Janave, M.T. 1997. Enzymic degradation of chlorophyll in 'Cavendish' bananas : In vitro evidence for two independent degradative pathways. Plant Physiol. 35 : 837-846.

Janave, M.T. and Sharma, A. 2004a. Partial purification and properties of chlorophyll degrading enzymes from 'Cavendish' banana (Musa cavendishi). Indian J. Biochem. Biophys. 41 : 154161.

Janave, M.T. and Sharma, a. 2004b. Inhibition of chlorophyll degradation in stay green 'Langra' mango (Mangifera indica L.) fruits. Indian J. Plant 
Physiol. 9 : 112-117.

Raychoudhary, R.; Kabir, J.; Ray, S.K.D. and

Dhua, R.S. 1992. Influence of preharvest spray of calcium salts in the improvement of fruit quality in guava cv. Lucknow-49. Adv. Hort. and Forestry. 2 : 70-76.

Sharples, R.D. and Johenson, D.S. 1977. Postharvest chemical treatment for the control of storage disorder of apples. Ann. Appl. Boil. 83(1) : 152-176.

Singh, B.P. and Narayana, C.K. 1999. An integrated approach for storage of mango. Indian J. Hort. 56(1) : 5-9.

Singh, R.V.; Tewari, J.D. and Chauhan, B.B.S. 1993. A note on the effect of different containers and packaging materials on the transpiration and storage behaviour of orange cv. Campbell Valencia. Prog. Hort. 25(3-4) :202-205

Singh, S.; Brahmachari, V.S. and Jha, K.K. 1998. Effect of calcium and polythene wrapping on storage life of mango. Indian J. Hort. 55(3) : 218-222.

\section{How to cite this article:}

Priya Awasthi, Subhash Chandra Singh and Shant Lal. 2021. Value Addition in Guava through Different Pre harvest Nutrient Sprays to Improve Sensory Attributes and Storability. Int.J.Curr.Microbiol.App.Sci. 10(02): 106-111. doi: https://doi.org/10.20546/ijcmas.2021.1002.012 